\title{
The First Female Shareholders of the Bank of New South Wales: Examination of Shareholdings in Australia's First Bank, 1817-1824
}

\author{
LEANNE JOHNS \\ School of Accounting and Business Information Systems, The Australian National University, Canberra, \\ Australia
}

ABSTRACT This paper examines female shareholdings in Australia's first bank, the Bank of New South Wales. Existing descriptions of colonial women have portrayed them generally as domestic servants, farmhands, prostitutes or wives and mothers, rather than as businesswomen or investors. But by 1823 the number of female shareholders represented 31 per cent, almost onethird, of total shareholders. Nevertheless, it seems that women were unable to take advantage of this potentially powerful position. Although they were allowed proxy votes, these could only be exercised by male shareholders. Thus, male shareholders acquired extra voting power through use of female shareholders' proxies, and seemingly employed the extra votes particularly when there were crucial or 'political' decisions to be made.

KEY Words: Shareholders, women in banking, colonial banks, corporate governance

\section{Introduction}

This paper provides a fresh perspective on the role of colonial women through the operations of the Bank of New South Wales in Sydney, during the period April 1817 to September 1824. ${ }^{1}$ Female shareholdings of the bank are identified from archival bank data and explored to determine whether women were investors in their own right (which might have been unusual in a colony not quite 30 years old) or whether there were other reasons and 'vested interests' which accounted for their shareholdings. In a penal colony, where most women were convicts or ex-convicts and those who were not were fully occupied in the home, status was very important and might have precluded such shareholdings. Further, while colonial women have been increasingly recognised as contributing in useful ways

Correspondence Address: L. Johns, School of Accounting and Business Information Systems, College of Business and Economics, The Australian National University, Canberra ACT 0200, Australia. Email: Leanne.Johns@anu.edu.au 
to the colony's development through their roles as wives, mothers, domestic servants, mistresses and prostitutes, and to some extent, as businesswomen, there is very little evidence to suggest that they were also investors. Their role was regarded by the male-dominated society as being principally confined to the private sphere.

The Bank of New South Wales (BNSW), as the first bank in Australia which continues today under the name of 'Westpac', holds an important place in Australian economic history. The issue of 'firstness' is rather a hackneyed concept and has sometimes been used to advance research. However, the issue of (first) female shareholders in a maledominated domain such as the BNSW 'Court of Proprietors', as bank shareholders were known, is of particular interest, given the unusual circumstances in Sydney at the time: it was a young, supposedly self-supporting, colony; it had not advanced commercially to the stage where it could have been said to have an 'economy' because of the lack of an export market; and, most significant of all, it was a gaol. ${ }^{2}$ In addition, the number of females in Sydney was extremely small: in November 1819 women comprised only 23 per cent of total adults 'in and around Sydney' (Vamplew, 1987: p. 25). In 1820, 60.5 per cent of colonial women were convict or emancipist women (Robinson, 1985: p. 71). The remainder were wives of free settlers and government officials. ${ }^{3}$ Convict and emancipist women constituted the majority of the female population until 1824 (Perrott, 1983).

Colonial women's involvement with the bank was first raised by Craig and Johns (2002). Their paper was directed to ascertaining the extent to which colonial women engaged in business and commercial activity, and was aimed at illustrating that colonial women were more involved in commerce than existing historical works have shown.

This paper examines more closely the possible reasons women acquired shares in the bank, and extends the period reviewed by Craig and Johns (2002), who only considered the period of the bank's first ledger, April 1817-June 1820. That time frame is extended here to 21 September 1824 - when the bank's second minute book ends. The omission from the literature of detail on colonial women's activities means that observable data in the BNSW records is important: it can offer valuable insights to colonial women's lives. The bank's first two minute books offer a complete record of all board and shareholders' meetings for the period 22 November 1816 to 21 September 1824. The bank's first ledger covers the period 8 April 1817 (when the bank opened) to 30 June 1820. Both sets of records contain details of share purchases and shareholdings.

The motivation for this paper is to ascertain who were the female shareholders and, if possible, to discover why they purchased their shares and to what extent they participated in the governance of the bank. Female shareholders did not initially have voting rights and there is no record of them having attended any shareholders' general meetings. However, the findings from this paper show that once a proxy vote was granted to female shareholders, not only did the female shareholding increase, but the female proxy vote was used by male proxies when crucial or important decisions were put to the vote. In this way, male shareholders who were not directors could still influence decision-making within the bank, because they were able to increase their voting power. The findings also show that a minority of female shareholders might have purchased their shares for investment or saving purposes.

The remainder of the paper is structured as follows: first, a discussion of the issue of colonial women and a brief comparison with female banking in England and Scotland 
in the seventeenth and eighteenth centuries. This is followed by an introduction to the BNSW and a description of its minute books. The results of the study, including brief descriptions of the female shareholders, are presented next. Finally, the implications of the findings, together with the limitations of the study are considered.

\section{Colonial Women}

Much has been written about the early colonial period in Sydney. However, in most colonial accounts, women were rarely mentioned and, if they were, it was in disparaging terms. Subsequent historians (e.g. Phillips, 1909; Clark, 1962; Robson, 1965; Shaw, 1966; Hainsworth, 1971) barely acknowledged any contribution to colonial development by colonial women. It is only since the advent of the women's movement in the late $1960 \mathrm{~s}$ that colonial females have been acknowledged as having a place in colonial society and colonial history (Summers, 1975; Dixson, 1976, 1999; Teale, 1978; Alford, 1984; Robinson, 1988; Oxley, 1996; Damousi, 1997; Daniels, 1998; Kociumbas, 1992; Perrott, 1983).

Most accounts of the lives of colonial women made one of two principal assertions. First, that there was no recognisable economic contribution by women to colonial development. Second, that there was an important contribution, but only in either a domestic, procreational or a sexual pleasure sense, through roles as servants, farmhands, wives, mistresses or prostitutes (Buckley \& Wheelwright, 1988; Oxley, 1988; Dixson, 1976, 1999; Lake, 1988; Byrne, 1993; Robinson, 1985; Alford, 1984). Only occasionally were colonial women acknowledged as businesswomen, but even this contribution was seen to be small (Perrott, 1983). Overall, there seemed to be little evidence to suggest that colonial women were businesswomen on anything other than a small scale.

Craig and Johns (2002), however, in their study on female involvement in the BNSW, found that there was a number of women (mostly married women and widows), who actively engaged in mercantile and commercial undertakings, and while some of this activity was, as Perrott (1983) claimed, on a small scale, there were some women who could qualify, with Mary Reibey, as colonial female entrepreneurs. ${ }^{4}$

Most females were convicts, with little education, opportunity and few prospects. Convict women occupied the lowest social strata in colonial society and were regarded, at worst, as prostitutes and, at best, as domestic servants and of little economic consequence. ${ }^{5}$ Free women, consisting mainly of wives of government officials, soldiers, free settlers or wives of convicts, were either fully occupied in the home or were servants, shopkeepers, or helped their husbands in their businesses (Robinson, 1988).

Upper-class colonial women did not work outside the home, domesticity being equated with femininity (Scott, 1996), and those few women in business were either emancipists or convict wives. Even a free wife of a convict was tainted with the 'convict' stain. Furthermore, trade was not deemed a respectable occupation. The English caste system dictated that 'gentlemen' could be wholesale traders but not retailers, and that to be 'in trade' was social death (Hainsworth, 1971: p. 36). Therefore, if a woman was married to a man in trade, her reputation was tainted also.

Colonial society was extremely patriarchal. Males dominated and controlled finance and trade and made most decisions. Women were not allowed a role in the public sphere, for example as businesswomen who were ambitious, enterprising and competent: their place was seemingly, to support men in their various endeavours. 
Aveling (1992: p. 149) points to the interplay between 'reproductive' work at home and 'productive' work in the marketplace, but concludes that power is the missing element. She claims that the patriarchal effects within the penal system sometimes advantaged convict women over convict men, and even over poor women in Britain. Further, women did not perform the hard labour tasks of clearing, building, rock-breaking and planting.

The writing of feminist history has tended to reduce diversities (e.g. class, race, ethnicity) among women so that, in the end, women have a common identity, usually in opposition to patriarchy (Scott, 1996). Following this line of thought would lead to the assumption that all colonial women were in opposition to the male-domination of colonial society, when this might not have been the case, certainly for upper-class colonial women and even, perhaps, for convict women, who might have accepted their fate with resignation. A British working-class woman expected to form a long-term monogamous relationship with a man from a similar background, to bear his children and be supported by him (Scott, 1996).

The question of a common identity of women was raised also by Riley (1996). She claims that there is no singular category of 'women'; women are a 'volatile collectivity' in which females can be very differently positioned (Riley, 1996: p. 18). Nowhere is this more obvious than when writing about colonial women: a gathering of females from all walks of life, with different skills and abilities and from different backgrounds. It would be easy to fall into a 'monofeminism trap', of assuming that all colonial women were the same (Mercer, 1975: pp. 50-51). Riley (1996) suggests that theories about histories of women could be modified by looking at the course of alignment into gendered categories. Colonial women were always defined by their social status (convict, free, married, single), but their status did not fully define them at all times. Convict women, in particular, were defined in terms of their position as sexual objects and yet that was not necessarily how they lived their lives, and certainly not all the time (Craig \& Johns, 2002).

Nevertheless, it is possible to describe history where women have been found to have occupied certain positions or spheres of influence without generalising about all women (in this case, colonial women).

\section{The Legal Position of Women}

Under English common law, coverture meant that a wife's property belonged to her husband after marriage. Legally, husband and wife were one entity and wives had no separate legal identity. Conversely, the husband became responsible for his wife's debts after marriage. Women could not enter into contracts in their own right, unlike single women, who were regarded as femes sole (Kercher, 1996). If a woman came to a marriage with separate property under a marriage settlement, she could act independently with regard to this property if a trust allowed for such action (Kercher, 1996). The British legal view seemed to regard married women's separate property as a means of providing secure maintenance for women and children, and judges were concerned to minimise the possibility that such property could be used as capital by women upon whom it was settled (Staves, 1990).

The legal position with regard to colonial women seems less clear. There was more commercial freedom for women in the colony of New South Wales (NSW) than might 
have been the case in England. While the colony applied English law, there were no juries and no local legislature (Kercher, 1996). The penal nature of the colony, the isolation from England and the unusual state of colonial society meant that sometimes courts made their own decisions, based on local circumstances. ${ }^{6}$ Colonial court records do not mention marriage settlements or trusts arising out of separate property before 1814. However, the earliest court cases regarding women's separate property showed that a woman married to a prisoner still serving his sentence could trade and contract debts as a feme sole and, thus, could not expect her husband to be liable for any debts she contracted in her own name (Lyons v. Cave (1827), Beale v. Raine (1829). Decisions of the Superior Courts of New South Wales, 1788-1899). This departure from British law was necessary because the husband, as a prisoner, was unable to sue or be sued or enter into contracts. Nevertheless, in NSW, wives of free men were also able to trade in their own names. This would only have been allowed in England if the husband consented to his wife being treated as a sole trader (Kercher, 1996).

\section{Women and Early Banking}

Female shareholders in UK banks were not unusual during the colonial NSW period. Subscribers to the Bank of England, when it opened in 1694, included 34 wives, widows and spinsters ('very often subscribed for by a male relation') out of a total of 1,272 subscribers (Clapham, 1945: pp. 273-276). By 1721 there were 'Dowagers, Duchesses, Countesses and Ladies' holding shares, and by the end of the eighteenth century the proportion of widows and spinsters was extraordinarily high (Clapham, 1945: pp. 281, 288). Mary Stanley, for example, was a widow from East Smithfield who owned $£ 350$ of stock in the Bank of England as far back as 1721 (Acres, 1931: p. 125). The only limitation to voting seems to have been the requirement to hold bank stock of $£ 500$ or more (Clapham, 1945: p. 279).

From Saville (1996: pp. 3, 29), it is clear that women were banking with the Bank of Scotland long before the BNSW opened. In 1696 three loans were made to women: Lady Hiltoun (£100), Dame Bethia Harper $(£ 1,000)$ and Dame Magdalen Kinloch (£150). However, all were titled upper-class women. Original subscribers to the Bank of Scotland included seven women. These women appeared to be from the aristocracy and landed gentry.

Colonial female shareholders did not fit these categories. Society in the colony was based on wealth, position and acquisition, not on hereditary aristocracy as in Britain. There was no aristocracy or landed gentry, at least for the first 30 years (Perrott, 1983: p. 30). There could be little comparison between a society with an entrenched, established class system and a penal colony where the greatest stigma was being a convict. It was more important to be classed as 'free' than anything else. Not only were none of the female shareholders titled women, but in some cases it was their husbands who qualified as 'rich merchants'.

It is unlikely that all colonial female shareholders would have held shares in British banks. Convict women would most likely not have had the means or the opportunity, had they remained in Britain. They might not have even been permitted to use banking services. In particular, ex-convict women (such as shareholders Roberts and Moore) could have been precluded from holding shares because of their criminal backgrounds. Share applications in the BNSW had to be approved by the board of directors, unless 
shares were acquired by transfer. The minutes do not record any vetoes to share applications by women during the period of the first minute books.

In addition, the BNSW female shareholders did not appear to be actively trading in shares, unlike women investors in the Bank of England, as Carlos and Neal (2004) found. The Sydney market was too small; there was no formal capital market (although an informal market probably existed) and the economy was fragile. Fortunes could be made and lost rapidly if the wrong decisions were made. However, it is quite possible that women bought shares for investment purposes, particularly single women or widows, who might have regarded the regular dividend stream as income.

\section{The Bank of New South Wales}

Governor Macquarie was instrumental in establishing the BNSW: he had convened a meeting of magistrates and merchants on 20 November 1816, to discuss currency difficulties (Bigge Report, 1966: pp. 65-66). At another meeting two days later it was decided to establish a bank (Holder, 1970). Several additional meetings followed, among them a public meeting held on 5 December 1816 to invite those who were interested in becoming subscribers (shareholders) to the bank to attend (Holder, 1970). Those present at the public meeting were told that Governor Macquarie's permission had been granted and subscription papers were handed out and signed by several present. ${ }^{7}$ Authorised capital of $£ 20,000$ was proposed, divided into 200 shares of $£ 100$ each. This was approved subsequently in Rule No. 2 of the BNSW's Rules and Regulations.

On 12 February 1817 the board met for the first time to approve a memorial to be presented to Governor Macquarie requesting a charter of incorporation as a joint stock company. The board felt it was important for the bank to have limited liability status because it would have more chance of success as shareholders would feel secure. Limited liability however, was attainable only by royal charter or special act. Macquarie was not certain he had the authority to grant such a charter but John Wylde, the JudgeAdvocate, convinced him it was an 'implied' authority and so Macquarie granted the charter. Subsequently it was rendered invalid. Lord Bathurst, in England, stated that Macquarie had no power to grant a charter, and was to inform the shareholders that they operated on the principles of an unlimited liability partnership (Butlin, 1953). Macquarie ignored this instruction and it is therefore interesting to conjecture whether any shareholders were aware of their potential liability. Certainly Macquarie's secretary (bank president J.T. Campbell) would have known. There was no mention of Bathurst's decision in the minute books. Either it was not discussed at board level (or any discussion was not recorded in minutes), or the other directors did not know.

The bank opened officially on 8 April 1817, after approval and adoption of its 50 rules and regulations by a general meeting of shareholders the previous day. ${ }^{8}$ Mary Reibey's house in Macquarie Place was chosen as bank premises and a two year lease for $£ 150$ per annum taken. The BNSW was essentially controlled by the board of directors but there were regular, at least six-monthly, meetings of the 'court of proprietors', or shareholders, generally to approve the accounts and elect directors. Extra meetings were called when there were important issues to be decided. There was no professional management as we would understand it today. The directors made all the decisions. If a change to bank rules and regulations was proposed, or there was an election for new directors, a general meeting of shareholders would be called. Usually a vote of thanks would be 
passed to the board by shareholders after the six-monthly financial report, indicating shareholders' acceptance of board governance. ${ }^{9}$

\section{The Minute Books}

The first official record of the bank's activities to be recorded in the first directors' minute book relates to the meeting held on 22 November 1816. The first two minute books provide a detailed account of all weekly and special meetings of the board of directors and of the periodic general meetings of shareholders.

There do not seem to have been any women involved in the establishment of the bank. No women were recorded as attending any meetings of shareholders during the period covered by the first two minute books. It is unlikely that they would have been present but unrecorded, as proceedings seem to have been conducted very formally. Certainly, there were no women recorded as taking part in discussions during any meetings. This suggests either that women were not differentiated from men or, perhaps more likely, that it had not occurred to the bank's founders that women might be interested in using bank facilities. The latter view would not have been totally unexpected, given colonial women's role in society at the time.

However, women did apply for shares and loans. They are identified either by use of the title 'Mrs', or by an obviously female first name. Thus, there is no difficulty in identifying women. There were no female joint or group shareholdings, unlike male deposit accounts where accounts were operated for partnerships and business combinations.

A complete list of shareholders and the number of shares each held was produced as part of the balancing process every half-year, together with a list of deposit accounts and balances. These are listed in the first ledger and are very useful in helping to identify female shareholders. Two lists of shareholders subsequent to the first ledger (i.e. post-30 June 1820) have been obtained from archival sources. ${ }^{10}$ The second of these lists does not give the size of shareholding, and hence it has not been included in this examination. However, the list provides the number of shareholders: thus, by the time the bank was granted its second charter on 31 October 1823, the number of female shareholders had grown to 18 out of a total of 59 . Women, therefore, represented 31 per cent of total shareholders in 1823 .

Requests for purchase of bank shares were recorded in the minute books. However, only the first two share transfers were recorded in the minute books: providing such transfers were registered at the bank, the directors did not have to give their assent. Consequently, if women acquired shares by transfer, as often happened, it is impossible to detect the timing. The new shareholder's name simply appears in the half-yearly listing.

It is clear from the minutes that gender and social standing played an important part in decisions made by the directors of the bank. Initially, women had no voting rights attached to their shares, and were not granted loans in their own names. ${ }^{11}$ However, with the granting of a female shareholder proxy vote in July 1819, from that time, female shareholders could potentially exercise power over bank decisions.

\section{Applications for Bank Shares}

At 31 December 1817, after the bank had been operating for almost nine months, there was one female shareholder, Margaret Campbell. Her $£ 100$ share was paid to $£ 75$. The total 
Table 1. Female shareholders at 30 December 1821

\begin{tabular}{llll}
\hline Margaret Campbell & 5 shares & Jemima Eagar & 1 share \\
Rachael Moore & 5 shares & Mary Ann Underwood & 1 share \\
Elizabeth Macquarie & 5 shares & Jane Roberts & 1 share \\
Alexandrina Sinclair Jones & 2 shares & Ann Jones & 1 share \\
Sarah Hazard & 1 share & Rosetta Terry & 2 shares \\
Esther Marsh & 1 share & & \\
\hline
\end{tabular}

Source: Mitchell Library, Bigge Appendix, Bonwick Transcripts Box 27, pp. 6292-6294, 30 December 1821

shareholdings at that date were $£ 3,625$ (Westpac Banking Corporation (hereafter WBC), BNSW ledger, 31 December 1817, f. 101). Her £75 share therefore represented 2.07 per cent of the paid-up capital. By 30 June 1820 there were eight female shareholders in the bank, having a total of 21 shares, all fully paid. By 30 December 1821, there were 11 female shareholders, having a total of 25 shares, all fully paid. Female shareholders and their shareholdings at December 1821 are shown in Table 1.

\section{Number of Female Shareholders}

Female shareholdings were, thus, reflected in the financial statements from the start of the bank's operations. In only one reporting period, the year ended 31 December 1818, were there no female shareholders, Margaret Campbell having transferred her share to her husband. ${ }^{12}$ But six months later, Elizabeth Macquarie purchased three shares and women were represented once again. By 31 December 1819 there were four female shareholders: Elizabeth Macquarie, Rachael Moore, Jane Roberts and Jemima Eager. The total number of shareholders was 53. Therefore, the proportion of total female shareholders to total shareholders was approximately 7.5 per cent. At 30 June 1820, when the number of female shareholders had doubled to eight, the total number of shareholders was 56, the proportion of total female shareholding likewise almost doubling, to 14.3 per cent. At 30 December 1821 this proportion had increased to 18.6 per cent, and by 31 October 1823 to 31 per cent. This was a large increase for a relatively short period of not quite four years. Not only did the number of female shareholders increase but so too did the number of shares held and the value of the female shareholdings.

\section{Value of Female Shareholdings}

The total value of the eight women's shareholding at 30 June 1820 was $£ 2,100$ (21 shares of $£ 100$ ), out of a total shareholding of $£ 12,500$ (WBC, BNSW ledger, 30 June 1820, f. 418), representing 16.8 per cent of total paid-up capital. This was a substantial proportion of total paid-up capital for any group, but particularly so for women. At 31 December 1819, six months earlier, the proportion of female shareholding had only been 9.22 per cent ( $£ 1,000$ out of a total of $£ 10,850$ ). The sudden increase is interesting. By 30 December 1821, the 11 female shareholders' percentage of total paid-up share capital of $£ 12,600$ had increased to 18.81 per cent. Not only had the number of 
female shareholders grown, but superficially at least, they held quite a powerful position in regard to the bank's operations. This was not so much because of their number, but the size of their shareholdings. It was the number of shares held that dictated a shareholder's voting power and, by this time, female shareholders had been granted a proxy vote.

Under the bank's rules and regulations, one share gave one vote: two shares, two votes. However, after that, voting rights were on a sliding scale. Four shares gave three votes, seven shares gave four votes and ten or more, five votes (BNSW, Rules and Regulations, Rule No. 15). There was some discussion regarding changing the rule to 'one share, one vote' at the board meeting on 18 May 1819. The directors resolved to refer the issue to a general meeting of shareholders but nothing seems to have come of it. There is a pencilled note in the margin of the minutes of the 18 May meeting that it was 'never resolved'. The next meeting of the shareholders, on 21 July 1819, was primarily for the purpose of approving the half-yearly accounts and presenting the President's report. Also to be decided was the issue of allowing a female proxy vote, as well as other bank business. The question of 'one share, one vote' does not seem to have even been raised, as there is no mention of it in the minutes for that meeting. ${ }^{13}$

Who were the female shareholders? Were they upper-class wives, or emancipist women? The motivation for the share purchases seems to have been consistent for most women, although circumstances differed. Therefore, each female shareholder's share acquisition will be discussed separately, in order of their 'appearance' in the bank records.

\section{The Female Shareholders}

\section{Margaret Campbell BNSW}

Insofar as the BNSW qualified as a public company, given the legal complexities and rejection of the bank's charter by the UK government, Margaret Campbell became the first woman to hold shares in a public corporation in Australia.

The original purchase of the share by Margaret is not noted in the minutes, but folio 101 in the ledger, 'Bank Subscriptions as at 31 December 1817', shows Margaret Campbell as having paid $£ 75$ (all three $£ 25$ calls) on one share. Three calls were made during the bank's first year, the third call being made 'on or before 7 December 1817', so sometime during that first year, Margaret purchased a share (WBC, BNSW Directors' Minute Book 1, 25 November 1817). At the time, her husband was an employee of the bank and hence not permitted to own shares.

Margaret Campbell (née Murrill) was born in the colony in 1795 so, in 1817, when she became a shareholder, she was just 22 years old. Margaret and Robert Campbell were married on 12 July 1812, under a licence granted by Governor Macquarie. ${ }^{14}$ Little is known about Margaret but her husband was a prominent and wealthy merchant. He was the nephew of Robert Campbell Senior and had ventured out to the colony at his uncle's urging (WBC, BNSW Directors' Minute Book 1, 23 December 1817). Campbell engaged in occasional commercial speculations while working for his uncle, and in 1810 asserted that he had accumulated $£ 1,000$ 'by speculations in trade and by fair dealings in the colony' (Steven, 1969: pp. 125-126). 
The BNSW minutes of 8 September 1818 record the transfer of Margaret's share stock to her husband. Rule No. 18 allowed for shares to be transferable by endorsement provided the transfer was notified to the bank and registered in the bank books.

Robert Campbell Junior resigned from the bank on 6 January 1818, 'as from 8 April' 1818 (WBC, BNSW Directors' Minute Book 1, 6 January 1818). The directors refused to discount a bill for him on 23 December 1817, on the grounds that it was 'in principle rejected' because he was the bank's accountant (WBC, BNSW Directors' Minute Book 1, 23 December 1817). Rule No. 46 precluded officers of the bank from carrying on any other business. Campbell was probably not adhering to that rule. His resignation might have occurred because it became impossible for him to continue his other business operations while acting as accountant to the bank. It is of interest that Campbell opened his ledger account on 1 November 1817, while still the accountant (WBC, BNSW ledger, 1 November 1817, f. 51).

The transfer of Margaret's shares to her husband forced the directors to produce a suitable form for the regular transfer of shares: 'by which form the Secretary and Cashier will only register Transfers in future: $\mathrm{He}$ will also get the transfer of Mrs. M. Campbell's shares made out in that form' (WBC, BNSW Directors' Minute Book 1, 2 September 1818). The first share transfer had already occurred in September 1817. Edward Riley had written to the board advising that Colonel Molle of the 46th Regiment was departing the colony and had made his share over to him. The board entered a copy of Riley's letter in the minutes (WBC, BNSW Directors' Minute Book 1, 28 October 1817). The directors must have considered the letter sufficient to authorise the transfer, although as the transfer had already taken place, there may have been little choice but to accept it. Margaret's transfer must have forced the board to formalise such transfer procedures.

Campbell had resigned from his bank position by the time the share transfer took place. It was not in Campbell's interests to keep the share in Margaret's name, given that women had no vote on any shares that they held at this time.

Margaret applied again for two shares on 23 February 1820, and a further share on 22 March 1820. This gave her three shares. In addition, George Howe and Joshua John Moore transferred their shares to her on 4 February 1820 and 10 May 1820, respectively. The transfers are noted on the back of the share certificates. The transfer of these two shares account for her shareholding of five shares (see Table 1). The transfers from Howe, who was the publisher of the Sydney Gazette, and Moore, a solicitor who worked as a clerk to the Judge-Advocate, might have occurred because they were short of funds. Alternatively, they might have been indebted to Campbell and he had accepted their shares as payment. Perhaps Campbell prevailed upon the two men to sell Margaret their shares.

By the time Margaret purchased her five shares, women were entitled to vote by proxy at shareholders' general meetings (as discussed below). Margaret's proxy was her husband, who by this time had three shares in his own right, so they had eight shares and five votes between them. This voting power may have been the reason for the split in the shareholdings between husband and wife. If Campbell had held the eight shares himself, he would have had only four votes. To obtain five votes, he would have had to buy ten shares which, at $£ 100$ each, would have meant a considerable outlay. 


\section{Elizabeth Macquarie}

After Margaret Campbell's share was transferred to her husband on 8 September 1818, there were no female shareholders until Elizabeth Macquarie, the Governor's wife, wrote to the board applying for two shares on 20 April 1819. She subsequently applied for another share on 22 June 1819 so that, by 30 June 1819, she was listed in the half-yearly accounts as having three shares, fully paid, and her shareholding of $£ 300$ represented 3.97 per cent of total shareholdings of $£ 7,550$, a sizeable shareholding for one woman (WBC, BNSW ledger, 30 June 1819, f. 402).

Whether Elizabeth Macquarie's first share purchase was the catalyst for the decision which eventuated at the directors' next meeting is a matter of conjecture. But at that meeting, on 27 April 1819, the directors moved 'that ladies, or females holding a share or shares of Bank Stock, altho' residing within the Territory, shall be entitled to vote by proxy' (WBC, BNSW Directors' Minute Book 1, 27 April 1819). Thus, this decision marked the beginning of women's voting rights.

This motion was ratified at a shareholders' general meeting on 21 July 1819 . The terminology is very interesting: 'ladies, or females'. This could have been how the bank distinguished class: respectable women of rank and standing were seen as 'ladies', emancipist women, who were considered far less respectable, were 'females'.

The other interesting point from the motion is the use of the phrase 'altho' residing in the territory'. This presumably means that even though female shareholders were physically able to attend meetings, they would not or could not do so. It is curious, because it raises the question of whether women did not want to attend such meetings, or whether male shareholders (especially female shareholders' husbands) did not want them to. Possibly it was a combination of both sentiments. Granting female shareholders a vote in itself was of considerable significance given that suffrage was not extended to women in Australia until the turn of the century. ${ }^{15}$

The above resolution rescinded a resolution made by the board on 3 February 1818 that no shareholder was allowed to vote by proxy. It is interesting to conjecture whether the whole issue arose initially because of Margaret Campbell's shareholding. Once the Governor's wife also became a shareholder, the board may have felt pressured to change the decision because of her high standing in the colony.

Elizabeth Macquarie exercised her right to vote by proxy for the first time on 17 August 1819 , less than a month after the proxy vote was granted, using the bank's President and her husband's secretary, John Thomas Campbell, as her proxy. This was after another shareholders' general meeting six days earlier resolved unanimously that the proxy 'which may be at any time appointed by ladies or females' had to be a shareholder of bank stock (WBC, BNSW Directors' Minute Book 2, 11 August 1819). Elizabeth continued to exercise her voting rights under proxy at subsequent general meetings of shareholders. On 16 February 1820 she purchased two more shares, giving her a shareholding of five shares at 30 June 1820. This gave her three votes.

Elizabeth Macquarie was devoted to her husband and fully supported his stand for emancipist inclusion in colonial society. She seems to have been an independent woman and buying her own shares in the bank could have reflected this. Alternatively, she could have done so at Macquarie's request, to demonstrate his faith in the bank, and also to give him some power, his secretary becoming Elizabeth's proxy. His position 
as Governor of the colony excluded him from buying shares. Elizabeth retained her shares after departing the colony because she was still listed as a shareholder when the bank charter was renewed in 1823 (NLA, Colonial Secretary's Correspondence, 26 November 1823, Reel 6040, SZ1049, pp. 70-73).

\section{Jane Roberts}

After Elizabeth Macquarie bought shares in the bank, several other women rapidly followed suit. This might indicate that Elizabeth Macquarie played a leadership or mentoring role in the colony for other women. As the Governor's wife, no doubt her approval would have been sought by other colonial women.

'Ann Roberts' applied for a share on 27 July 1819. This share is shown subsequently as belonging to 'Jane Roberts'. Ann was Jane's daughter, and was born in the colony. She could have applied for the share on Jane's behalf because Jane was illiterate or, more likely, because Jane was an emancipist and might not have been allowed to purchase a share (NLA, Colonial Secretary's Correspondence, 3 June 1820, Reel 6049; 4/1744 pp. 342-349, 358). The minutes of 10 August 1819 record the share as being made out to Ann, but it must have been transferred to Jane. The list of shareholders at 30 December 1819 shows Jane Roberts as holding one share (WBC, BNSW ledger, 31 December 1819, f. 408). Importantly, this made her the first female emancipist shareholder.

Ann married wealthy emancipist merchant Solomon Levey, which explains why he was Jane's proxy at shareholders' general meetings (Liston, 1992). Why did Jane take up the share? Ann could have been Levey's proxy, as his wife. However, Jane's husband had died in 1819 , so perhaps she was trying to invest in her future as a single mother with a large family. When her husband died she was left a wealthy woman - her bank deposit account reflects an opening deposit on 12 June 1820 of $£ 600$, probably part of the remaining amount owing from her husband's road contract. It is possible that Jane was purchasing her share for investment purposes. In England bank stock was used in marriage settlements and to support widows and spinsters of noble, gentle or City families (Clapham, 1945).

Jane's late husband was emancipist William Roberts, who was one of the original subscribers to the bank, although he did not take up any shares (WBC, BNSW Directors' Minute Book 1, 5 December 1816). There is no record of him doing so in the ledger or minute books. His illiteracy may have prevented him, or perhaps he was too busy. Roberts was a very successful businessman, eventually becoming one of Macquarie's major road builders (Hainsworth, 1971). He is said to have grossed over $£ 10,000$ in building contracts over seven years (Ville, 1998). Jane took over his business interests when he died.

The first time Jane exercised her proxy vote, a heated argument ensued among the shareholders. Levey's written authorisation from Jane was considered invalid because it was not registered or witnessed by the bank secretary. Immediately, emancipist Edward Eagar moved (seconded by emancipist Robert Murray), that the authorisation be accepted. An objection was then made to Murray seconding the motion because he had only become a shareholder the previous day. Captain John Piper moved that any shareholder holding share stock for less than three months should be entitled to move or second any question at a shareholders' meeting. This was put to the vote under a closed ballot and a majority 
voted in favour of Piper's motion. Next, Eagar's motion was voted on and a majority voted in favour. However, the shareholders then passed a motion that any future proxies of 'lady' shareholders be refused unless witnessed and left with the bank secretary for registration, at least three days prior to a shareholders' general meeting (WBC, BNSW Directors' Minute Book 2, 9 August 1820). It is interesting that this time only the term 'lady' is used. Presumably this description included emancipist Jane Roberts.

The shareholders' general meeting above took place on 9 August 1820. The reaction of the shareholders, both emancipist and free, indicates how fragile relations were between the two. Was there a deliberate obstruction to Jane Robert's proxy being accepted? If so, was it because of her emancipist status, or because she was a woman? Or was it because Levey, her proxy, was an emancipist who had once been refused a bill for discounting because he was a prisoner? (WBC, BNSW Directors' Minute Book 1, 4 August 1818). The circumstances surrounding Jane Roberts' proxy indicate that there was opposition to either her or her proxy vote. This is curious, given that Elizabeth Macquarie had used her proxy vote earlier, on 17 August 1819. Were the directors deliberately differentiating between the governor's wife and an emancipist widow? There was opposition to emancipists becoming directors of the bank; was there a subtle push by the directors to stifle emancipist voting power so as to maintain this state of affairs?

Jane married William Hutchinson, wealthy emancipist, in 1825. Hutchinson subsequently became her proxy (WBC, BNSW Directors' Minute Book 2, 20 February 1822; NLA, NSW Pioneers', Register of Births, Deaths and Marriages).

\section{Rachael Moore}

One day after the rather fiery general meeting noted above, Rachael Moore, 'of Moorebank, Liverpool' applied for five shares (on 10 August 1819). She became the second female emancipist shareholder. The timing of her share purchase is most interesting. She was a good friend of Governor and Mrs Macquarie, who were both very supportive of emancipist inclusion in colonial society. Was this a political decision? Was Jane Roberts' share purchase a deliberate 'testing of the water' for other female emancipists?

Rachael Moore's husband Thomas did not have shares at this time, but applied for five shares 'in his own name' on 16 September 1819 (WBC, BNSW Directors' Minute Book 2, 16 September 1819). Thomas Moore is described as a 'sailor, farmer and philanthropist', with little education and a stable character. He arrived in the Britannia in 1791 and became the colony's master boatbuilder. Subsequently, he became a magistrate and one of the colony's largest landholders. When he died his bequest was used to help found the Moore Theological College (Australian Dictionary of Biography (hereafter ADB), 2: pp. 254-255). Rachael arrived in 1790 as a convict on the Lady Juliana (Baxter, 1988b).

Curiously, despite her husband being a bank shareholder, Rachael used J. T. Campbell as her proxy. This adds weight to the suggestion that her shareholding was a deliberate political ploy. Campbell, as bank president and Macquarie's secretary, could have been operating the bank under Macquarie's instructions. And as the Macquarie's good friend, Rachael Moore might have been happy to comply. With three proxy votes from Elizabeth Macquarie and three from Rachael Moore, Campbell had an extra six votes. At 30 June 1820 , he had 12 shares, or five votes, so effectively his voting power was more than doubled by the proxies. This might have been very important when he had the casting vote, as bank president, or could influence, with his vote, which way a decision would go. 
The first shareholders' general meeting at which Rachael was eligible to vote was a special meeting called by 11 of the shareholders regarding the rules and regulations concerning the 'indorsers, indorsements and discount of bills presented for discount' ${ }^{16}$ At this time the directors were rejecting as many bills for discount as they were approving, because of the decision by the board on 25 January 1819, regarding signature or endorsement of three people to every bill or note. At this meeting on 17 November 1819, that resolution was rescinded. Elizabeth Macquarie and Rachael Moore voted by their proxy John Thomas Campbell. However, neither woman was represented at the next general meeting of shareholders on 18 January 1820.

\section{Jemima Eagar}

Jemima Eagar must have acquired her share by transfer some time between 30 June 1819 and 31 December 1819, because there is no mention of a share purchase by her in the minutes. Her husband Edward was a prominent shareholder in the bank. He owned two shares so together they had three votes, with Jemima having one vote, and Eagar having two. Had Eagar owned all three shares himself, he would have only had two votes.

Purchasing a share for Jemima could have been a very clever ploy by Eagar to retain his original three votes while only owning three shares. When the bank was founded, Eagar became the largest shareholder. At 30 June 1818 he is shown as having five fully paid shares. However, by 31 December that year, Eagar had divested himself of three shares, his shareholding reduced to $£ 200$ (two shares). By purchasing a share in his wife's name, Eagar was back to his original three votes, for he became Jemima's proxy at subsequent shareholders' general meetings.

Eagar was one of the more enthusiastic and outspoken emancipist leaders. He was a lawyer, transported for forgery in 1811. His law practice in Sydney was interrupted in 1815 by the legal decision that he could not practice because his name had not been inserted in a general pardon under the great seal ( $A D B, 1$ : pp. 343-344). Eagar may have been motivated to acquire more voting power so that his views would carry more weight. He would have been well versed in company law.

Jemima Eagar was born in the colony, the illegitimate daughter of John McDuel and Margaret Malony. She married Eagar in 1815. Jemima had four children by Eagar and also a son by William Charles Wentworth in 1830. Eagar returned to Britain in 1821 (Ritchie, 1997). He never returned to New South Wales (ADB, 1: p. 344). Jemima remained in the colony with their children.

Jemima's proxy (following her husband's departure in 1821) became Francis Ewan Forbes, emancipist merchant and partner of James Underwood and Eagar (Dow, 1974).

\section{Alexandrina Sinclair Jones}

Alexandrina Sinclair Jones applied for two shares on 11 April 1820. Very little is known about her other than that she was the widow of Captain Jones of the Bridgewater. She arrived in the colony on the Bombay from Calcutta via the Derwent on 7 December 1819 (Mitchell Library (hereafter ML), James Bonwick Transcripts, Box 19, p. 2932). She seems to have been wealthy, and is recorded as possessing a store receipt for the substantial sum of $£ 300$, on 21 December 1820 (ML, James Bonwick Transcripts, Box 25, p. 5366). 
Alexandrina did not use a proxy vote during the period of the first ledger, and still had her shares when the second charter was granted to the bank in 1823 (NLA, Colonial Secretary's Correspondence, 26 November 1823, Reel 6040, SZ 1049, pp. 70-73). She might have been another female shareholder who owned shares as an investment. There were considerable profits accruing to share ownership, for example, dividends paid were 12 per cent in February 1819, another 12 per cent in July 1819, and 9 per cent and 6 per cent respectively in January and August 1820. These were substantial dividends for a small bank.

\section{Ann Jones}

Ann Jones acquired a share sometime between 31 December 1819 and 30 June 1820, by transfer. She appears in the list of shareholders in the ledger at 30 June 1820, as having one share (WBC, BNSW ledger, 30 June 1820, f. 414).

Ann Jones used Thomas MacVitie as her proxy. Ann was born in the colony, the daughter of Joseph and Ann Jones, and became housekeeper to MacVitie (Baxter, 1988b). They married in 1824 ( $A D B, 2$ : pp. 196-197).

MacVitie had four shares, or three votes. Ann's share gave him four votes. To obtain four votes himself, he would have had to buy seven shares, or three more. MacVitie would have been well-versed in banking practice, because he was one of the 'principal merchants' invited to help establish the BNSW. He was one of the original shareholders and was elected to the board of directors in 1821 ( $A D B, 2:$ p. 196).

\section{Mary Ann Underwood}

Mary Ann Underwood's husband James applied for two shares, one for each of them, on 21 June 1820. Mary Ann did not use her right of proxy vote until the meeting on 1 February 1822, when her husband was her proxy. She was still listed as a shareholder in 1823 (NLA, Colonial Secretary's Correspondence, 26 November 1823, pp. 70-73, 31 October, p. 2, Reel 6040, SZ 1049).

Underwood was an emancipist shipbuilder, distiller and merchant (ADB, 2: p. 547; ML, Mutch Index, 78/77). Mary Ann was born in the colony in $1796 .{ }^{17}$ Underwood has been described as one of the colony's outstandingly successful emancipists (Steven, 1969). He was a boat builder in partnership with Henry Kable in his early years in the colony. In his accounts a figure (possibly inflated) of $£ 26,000$ has been mentioned for the work done during the years 1805 to 1809 . Later, in 1812, he opened a coffee house and held a spirit licence ( $A D B, 2$ : pp. 546-547; Sydney Gazette, 27 June 1812). It is quite probable that Mary Ann assisted him in his business ventures.

\section{Sarah Hazard}

Sarah was the wife of Robert Hazard, merchant, and was publican of the Greyhound (NLA, Colonial Secretary's Correspondence, Reel 6038; SZ 759, p. 340). She is listed as having one share at 30 December 1821. There is no record in the minute books of her having used her proxy vote. Her husband had died by May 1820 (ML, Wentworth Papers, D.1, p. 218). Perhaps her share purchase was intended as an investment, but she 
was unable to sustain it: Sarah had ceased to hold her share by 1823 (NLA, Colonial Secretary's Correspondence, 31 October 1823, Reel 6040; SZ 1049, p. 2).

\section{Rosetta Terry and Esther Marsh}

Noted colonial businesswoman Rosetta Terry was the wife of Samuel Terry, the 'Rothschild of Botany Bay' (Dow, 1974). ${ }^{18}$ She acquired two shares (and thus, two votes) by 30 December 1821, and her daughter, Esther Marsh, had one share. This would have given Terry three proxy votes as both women gave him their proxies.

There is no available data on how many shares either held after that, other than Terry having four proxy votes at the shareholders' general meeting on 1 February 1822 (WBC, BNSW Directors' Minute Book 2, 1 February 1822). These extra votes helped secure Terry's election as director: at that meeting there were 29 votes in favour, and 24 against. However, three days later, the directors met and decided that Terry could not assume a directorship because he was not 'absolutely and unconditionally free' as required by the charter. He had served his sentence and had been free since 1807 but had neglected to seek a full pardon under the Great Seal of England (Holder, 1970).

Terry had stood for election to the directorship on three prior occasions: 1818,1819 and 1820 (WBC, BNSW Directors' Minute Book 2, 20 February 1822). The next general meeting of shareholders on 20 February 1822 was well attended: clearly many of the emancipist shareholders were tired of the board continually rejecting Terry's attempts to be elected as director. But Terry's election was not upheld. One of the emancipist shareholders, Francis Ewan Forbes, asked the board to explain their action in excluding Terry. After much discussion, the ex-bank President, John Thomas Campbell, moved that the decision was based on legal grounds and that Terry could take legal action if he felt aggrieved; this was seconded by D'Arcy Wentworth and eventually passed.

It is interesting that there were 18 female proxy votes used at this meeting: at the previous meeting, there were only 14 . Either the pro-Terry camp was there in force to see justice done, or the reverse, free shareholders (including the board) were determined not to see him elected. ${ }^{19}$

Appendix A summarises the effect of female proxy votes on total votes at the shareholders' general meetings at which proxy votes were used. The percentage of proxy votes to total votes rose from 5.7 per cent on 17 August 1819, the first time a proxy vote was used, to 24 per cent on 7 September 1820. The proportion of proxy votes to total votes was dependent on how many male shareholders attended meetings so, in some respect, Appendix A shows the potential that existed for female proxy votes to influence decisions.

Table 2 illustrates total shareholder voting power for each financial period, and compares available male and female voting numbers. These figures are comparisons only as to the distribution of potential voting power between male and female shareholders. Female voting rights were not actually granted until 21 July 1819 . The table shows a comparison between total available male votes and total available female votes at the end of each financial period. Female votes are then calculated as a percentage of total available votes. The result illustrates the potential for female proxy votes to influence total votes at shareholders' general meetings. By 30 June 1820, potential female proxy votes constituted 15.46 per cent of total votes available, and by 30 December 1821 , almost 19 per cent. 
Table 2. Comparison of total shareholder voting power by gender

\begin{tabular}{lcccc}
\hline $\begin{array}{l}\text { Financial period } \\
\text { ending }\end{array}$ & $\begin{array}{c}\text { Total available } \\
\text { male votes }\end{array}$ & $\begin{array}{c}\text { Total available } \\
\text { female votes }\end{array}$ & $\begin{array}{c}\text { Total available votes } \\
\text { (both genders) }\end{array}$ & $\begin{array}{c}\text { Female votes as } \% \\
\text { of total votes }\end{array}$ \\
\hline $31-12-1817$ & 46 & 1 & 47 & 2.13 \\
$30-06-1818$ & 61 & 1 & 62 & 1.61 \\
$31-12-1818$ & 63 & 0 & 63 & 0.00 \\
$30-06-1819$ & 63 & 2 & 65 & 3.10 \\
$31-12-1819$ & 78 & 7 & 85 & 8.24 \\
$30-06-1820$ & 82 & 15 & 97 & 15.46 \\
$30-12-1821$ & 82 & 19 & 101 & 18.81 \\
\hline
\end{tabular}

Source: WBC, BNSW ledger, ff. 101 (31 December 1817), 105 (30 June 1818), 301 (31 December 1818), 402 (30 June 1819), 407 (31 December 1819) and 414 (30 June 1820)

It is interesting to note, comparing Table 2 with Appendix A, that there were many shareholders who did not attend general meetings and thus exercise their voting power. In contrast, the female proxy vote was used at the first meeting after approval was given to do so. Table 2 demonstrates the connection between the granting of the female right to a proxy vote, and the increase in female shareholders. Available female proxies rose from two at 30 June 1819, to 19 by 30 December 1821 .

\section{Conclusions and Limitations}

The minute books thus revealed that there were 11 female shareholders in the Bank of New South Wales between its inception on 8 April 1817 and 30 December 1821. Further, using other archival sources, at 31 October 1823, there were 18 female shareholders. So between 30 December 1821 and 31 October 1823, a further eight women acquired shares (Sarah Hazard had disposed of her share). ${ }^{20}$ It is interesting that Sarah Hazard was the only one of the original eleven shareholders missing at 31 October 1823 when the second charter was issued. Thus, there was no high turnover of female shareholdings: they remained loyal shareholders, with the exception of Sarah Hazard. Unlike female shareholders in the Bank of England, they did not trade in shares. Possibly this was due to the lack of a capital market but it might also have been because it was only the early beginnings of the BNSW.

Two female shareholders were known ex-convicts: Jane Roberts and Rachael Moore. As far as can be ascertained, the other women came free or were born in the colony. This suggests that the directors, since they were 'free' themselves, might have been discerning about who could buy shares. It is unlikely that the bank directors would have wanted colonial women without wealth and status to have any influence over bank decisions, in the event of them being granted full voting rights. In any case, it was advantageous for the bank to have wealthy and high-standing shareholders; this could only add to the bank's reputation, increase shareholder confidence and attract new shareholders. Alternatively, perhaps, other ex-convict women did not have the money with which to buy shares. However, by the time Moore acquired her shares, she had been the wife of a respectable citizen for several years, and Roberts had been married to a man who, although an emancipist, was highly respected as a major road-builder in the colony. 
These two women did not fit the profile of the 'damned whore' stereotype convict woman who was a servant or prostitute.

The first conclusion from this study is that the pattern in the female shareholdings seems generally to indicate that it was for the purpose of increasing the voting power of male proxies. Male shareholders were able to circumvent the sliding voting scale by increasing their voting power without the necessity of buying more shares. The ability of male shareholders to increase their voting power by using a female proxy vote might be the reason for the rapid increase in the number of female shareholders.

There might have been exceptions, however, for single and widowed women: they could have been looking for a profitable investment and accepted that their votes would be given to male proxies. Emancipist widow Jane Roberts might have been unable to purchase her share without the help of her daughter's husband (who was her proxy). Another widow, Anne Minchin, assigned her proxy vote to the bank president, John Piper. Two widows, however, Alexandrina Sinclair Jones and Sarah Hazard, did not assign their proxy vote. Their interest might have been solely in dividends.

Why did female shareholders go along with this? Not all shareholders had husbands as proxies. They could have decided (like Jones and Hazard) not to use a proxy. Did they not challenge this state of affairs? Whether male proxy vote holders were communicating preferences of female shareholders is a matter of conjecture. But it is clear that women were prevented from directly making their views known. It seems that Aveling (1992) was correct when she concluded that colonial women submitted willingly to both patriarchal public order and patriarchal private order.

The other interesting conclusion is that it seems that proxy votes were only used when there were important decisions to be made at shareholders' meetings. This is particularly evident in Samuel Terry's case, when he was attempting to achieve election as director. At the half-yearly meetings held to 'approve the accounts', or other routine general meetings (for example, to appoint new staff), there were no proxies used, and often few male shareholders present.

The obvious limitation to this study is the lack of available data on female shareholdings beyond the period covered by the first minute books. Further research to determine 'what happened next' would be useful, particularly regarding the issue of women's votes.

Very little is known of colonial women's involvement in colonial commercial affairs, or of their activities and place in colonial society. This paper has shed light on one aspect of colonial women's lives. It has also highlighted the part women's shareholdings played in the decision-making processes of the BNSW male shareholders; how male shareholders were able to circumvent the bank rules regarding allocated votes per shareholding, and how they took advantage of their proxy votes when political or other important decisions had to be made. Thus, the paper adds to what little is known of early Australian corporate governance.

\section{Acknowledgements}

The author is grateful to Russell Craig, Simon Ville and Margaret Steven for comments on earlier versions of this paper. Thanks are also due to the two anonymous reviewers for their helpful comments. I also thank the staff of the Historical Services Section, Westpac Banking Corporation Ltd, Sydney, for their generous assistance. 


\section{Notes}

1. This specific time frame was chosen because it is the period covered by the first accounts ledger (April 1817-June 1820) and the first two minute books of the Bank of New South Wales.

2. The colony's status as a penal colony affected conditions for not only convicts, but for free people as well. Convicts dominated the labour market and society became divided into respectable and nonrespectable classes, with respectability being prized (Neal, 1991: pp. 52-53).

3. 'Free' women means those who were not convicts or ex-convicts. Some convicts were pardoned before expiration of their sentence, and were called 'emancipists', while others served their sentence or were granted tickets-of-leave (occasionally upon arrival in the colony, for example, John Croaker, see Booker \& Craig, 2000: p. 77). For the purpose of this paper, all ex-convicts will be termed 'emancipists'.

4. Mary Reibey is said to be Australia's first (and, by most authors, only) colonial female entrepreneur. She was estimated to be worth $£ 20,000$ in 1816 (Steven, 1992: p. 53).

5. Aveling (1992) claims that gender helped shape colonial society in that the British government had an ideal gender order in mind with regard to the colony; every man should have a woman who would reproduce. This meant that wives were in subordinate and apolitical roles. Scott (1996) maintains that gender is a primary means of signifying relationships of power. However, in a penal colony like Sydney, issues of power (as government official/officer male dominance) become complicated when gender is considered.

6. Society was composed of free settlers, convicts, emancipists, government officials and military officers. Neal (1991) maintains that this eclectic mix made for different problems and necessitated new rules regarding formal legal positions, for example, who was a fit person to hold public office. One of the biggest issues was whether the English caste system would be recreated in New South Wales (Neal, 1991: pp. 16-17).

7. William Roberts, husband of Jane, one of the first female shareholders, was one of the signatories.

8. On 18 December 1816, a general meeting of subscribers (prospective shareholders) elected a committee to frame regulations for the management of the bank. All rules were carried unanimously except for rule no. 7, which was carried on a division. This rule stated that subscribers had to be 'absolutely and unconditionally free' to be eligible as directors. That this rule was contested illustrates the distrust that existed among free colonists of convicts. It also indicates that there were some subscribers who did not meet the bank's requirements.

9. There were, however, some exceptions to shareholder acquiescence. On 18 July 1822, at the general meeting called to consider the half-yearly accounts, one of the shareholders (emancipist Francis Ewan Forbes) moved (seconded by Samuel Terry) that the proposed vote of thanks to the directors and president 'for the able and faithful discharge of their duties' be amended to substitute the word 'delinquent' for 'faithful'. The motion was carried with the amendment, by a majority of two votes.

10. The bank's second ledger was not retained but a list of shareholders was supplied to Commissioner Bigge in 1821. He was appointed by the British Government to enquire into the colony's administration. Another shareholder list was produced when the second charter of the bank was drawn up in 1823. (Mitchell Library, Bigge Appendix, Bonwick Transcripts Box 27, pp. 6292-6294, 30 December 1821; National Library of Australia (hereafter NLA), Colonial Secretary's Papers, Reel 6040, SZ 1049, p. 2, 31 October 1823).

11. Mary Collits applied for a loan of $£ 25$, on security of a land grant of 70 acres, on 27 May 1817, but was only granted the loan 'on said security being joined therein by her husband Pierce Collits'. Despite the fact that Mary had come free and Pierce was an ex-convict, she was still unable to obtain a loan in her own right. Charlotte Wairs applied for a $£ 20$ loan jointly with John Mittens, on 2 September 1817: the loan was approved immediately. Even the BNSW's landlady, Mary Reibey, was unable to obtain a loan (of £500) on 16 February 1820. The board of directors refused, stating that the board had already advanced loans to the full amount of its entitlement by the bank's charter (NLA, Colonial Secretary's Correspondence, 1 July 1803, Fiche 3268, 9/2731, p. 132; WBC, BNSW Directors' Minute Book 1, 27 May 1817; WBC, BNSW ledger, 8 September 1817, ff. 463-464; WBC, BNSW Directors' Minute Book 2, 16 February 1820).

12. By this time he had ceased employment with the BNSW and was permitted to own shares.

13. It is interesting that when the second charter of the bank was formulated in 1823, the chance to alter the voting rights does not seem to have been taken (at least, there is no mention in the minutes that it was). 
The same voting rights as in the first charter were reiterated. Perhaps the directors at the time and those on the special committee formed to draw up the new charter did not consider existing voting rights to be a problem.

14. The marriage took place on their child's first birthday (ML, Mutch Index).

15. In some colonies however, women secured earlier the right to vote in municipal elections.

16. One of the directors' main tasks at weekly board meetings was discounting bills of exchange and promissory notes.

17. Mary Ann Powell was born in the colony on 17 June 1796, the daughter of Edward and Elizabeth Powell, Edward being a free settler, farmer and victualler and owner of the Half-way House Inn on Parramatta Road (Sydney Gazette, 24 August 1816).

18. Rosetta Terry had come free on the infamous Hillsborough, as the wife of convict Edward Madden. He died on the voyage and she married or was the mistress of convict Henry Marsh. After his death she established herself as an astute businesswoman, providing for her three children. She married Samuel Terry in March 1810 (ADB, 2: p. 508; Clune, 1964: p. 71).

19. This result illustrates what Pearson (2002) found with respect to early English joint stock companies: shareholders were frequently outmanoeuvred by the board and other more powerful shareholders. They often had little power and operations were seldom transparent. This seems to have been the case with Terry.

20. The eight new shareholders were Mary Ann Forbes (wife of Francis Ewan), Anne Minchin (wife of the late William - possibly she took over his share. Her proxy was bank president John Piper), Elizabeth Hassall (her proxy was Francis Ewan Forbes), Jemima Jenkins (wife of prominent merchant Robert), Emma Josephson, Sarah Redfern (wife of William), Maria Chalker and Sarah Allman.

\section{References}

\section{Primary Sources}

Mitchell Library, State Library of New South Wales, Sydney.

Bonwick, J. Transcripts, Boxes 19, 25, 27.

Mutch, T.D., Index of Births, Deaths and Marriages 1787-1814.

Wentworth Papers, D.1.

National Library of Australia, Canberra.

Colonial Secretary's Papers, 1788-1825: microfiche and microfilm collection.

New South Wales Pioneers' Register of Births, Deaths and Marriages.

Sydney Gazette, microfilm collection.

Westpac Banking Corporation, Sydney.

Bank of New South Wales, First Ledger and Directors' Minute Books 1 and 2.

\section{Secondary Sources}

Acres, W. M. (1931) The Bank of England from Within 1694-1900, Vol. 1 (London: Oxford University Press).

Alford, K. (1984) Production or Reproduction? An Economic History of Women in Australia 1788-1850 (Melbourne: Oxford University Press).

Aveling, M. (1992) Bending the bars: convict women and the state, in: K. Saunders \& R. Evans (Eds) Gender Relations in Australia: Domination and Negotiation, pp. 144-157 (Sydney: Harcourt Brace).

Australian Dictionary of Biography, Vols 1 and 2 (Melbourne: Melbourne University Press).

Baxter, C. (1988a) (Ed.) General Muster of New South Wales 1811 (Sydney: Australian Biographical and Genealogical Record).

Baxter, C. (1988b) (Ed.) General Muster of New South Wales 1822 (Sydney: Australian Biographical and Genealogical Record).

Bigge Report on Agriculture and Trade in NSW (1966) facsimile edition (Adelaide: Libraries Board of South Australia).

Booker, J. \& Craig, R. (2000) John Croaker: Convict Embezzler (Melbourne: Melbourne University Press). 
Buckley, K. \& Wheelwright, T. (1988) No Paradise for Workers (Melbourne: Oxford University Press).

Butlin, S. J. (1953) Foundations of the Australian Monetary System 1788-1851 (Melbourne: Melbourne University Press).

Byrne, P. J. (1993) Criminal Law and Colonial Subject (Cambridge: Cambridge University Press).

Carlos, A. M. \& Neal, L. (2004) Women investors in early capital markets, 1720-1725, Financial History Review, 11(2), pp. 197-224.

Clapham, J. (1945) The Bank of England: A History, Vols 1 and 2 (New York: Macmillan).

Clark, C. M. H. (1962) A History of Australia (Melbourne: Melbourne University Press).

Clune, F. (1964) Bound for Botany Bay (Sydney: Angus and Robertson).

Craig, R. \& Johns, L. (2002) Female customers of the Bank of New South Wales 1817-1820, Journal of the Royal Australian Historical Society, 88, pp. 162-175.

Damousi, J. (1997) Depraved and Disorderly (Melbourne: Cambridge University Press).

Daniels, K. (1998) Convict Women (Sydney: Allen and Unwin).

Decisions of the Superior Courts of New South Wales, 1788-1899, published by the Division of Law, Macquarie University, <http://www.law.mq.edu.au/scnsw > .

Dixson, M. (1976, 1999) The Real Matilda (Sydney: University of New South Wales Press).

Dow, G. M. (1974) Samuel Terry: the Botany Bay Rothschild (Sydney: Sydney University Press).

Hainsworth, D. (1971) The Sydney Traders (Melbourne: Cassell).

Holder, R. (1970) Bank of New South Wales: A History (Sydney: Angus and Robertson).

Kercher, B. (1996) Debt, Seduction and Other Disasters: The Birth of Civil Law in Convict New South Wales (Sydney: The Federation Press).

Kociumbas, J. (1992) The Oxford History of Australia, 1770-1860 (Melbourne: Oxford University Press).

Lake, M. (1988) Convict women as objects of male vision, Bulletin of the Centre for Australian Historical Studies, 2(1), pp. 40-48.

Liston, C. (1992) Colonial society, in: J. Broadbent \& J. Hughes (Eds) The Age of Macquarie, pp. 19-34 (Melbourne: Melbourne University Press).

Mercer, J. (1975) The Other Half: Women in Australian Society (Sydney: Penguin Books).

Neal, D. (1991) The Rule of Law in a Penal Colony (Cambridge: Cambridge University Press).

Oxley, D. (1988) Female convicts, in: S. Nicholas (Ed.) Convict Workers, pp. 85-97 (Cambridge: Cambridge University Press).

Oxley, D. (1996) Convict Maids (Cambridge: Cambridge University Press).

Pearson, R. (2002) Shareholder democracies? English stock companies and the politics of corporate governance during the industrial revolution, English Historical Review, cxvii (473), pp. 840-866.

Perrott, M. (1983) A Tolerable Good Success (Sydney: Hale and Iremonger).

Phillips, M. (1909) A Colonial Autocracy (Sydney: Sydney University Press).

Riley, D. (1996) Does sex have a history? in: J. W. Scott (Ed.) Feminism and History, pp. 17-33 (Oxford: Oxford University Press).

Ritchie, J. (1997) The Wentworths: Father and Son (Melbourne: Melbourne University Press).

Robinson, P. (1985) The Hatch and Brood of Time (Melbourne: Oxford University Press).

Robinson, P. (1988) The Women of Botany Bay (Sydney: Macquarie).

Robson, L. L. (1965) The Convict Settlers of Australia (Melbourne: Melbourne University Press).

Saville, R. (1996) Bank of Scotland (Edinburgh: Edinburgh University Press).

Scott, J. W. (1996) (Ed.) Feminism and History (Oxford: Oxford University Press).

Shaw, A. G. L. (1966) Convicts and the Colonies (London: Faber and Faber).

Staves, S. (1990) Married Women's Separate Property in England, 1660-1833 (Cambridge, MA: Harvard University Press).

Steven, M. (1992) Public credit and private confidence, in: J. Broadbent \& J. Hughes (Eds) The Age of Macquarie, pp. 48-59 (Melbourne: Melbourne University Press).

Steven, M. (1965) Merchant Campbell 1769-1846 (Melbourne: Oxford University Press).

Steven, M. (1969) Enterprise, in: G. J. Abbott \& N. B. Nairn (Eds) Economic Growth of Australia 1788-1821, pp. 119-38 (Melbourne: Melbourne University Press).

Summers, A. (1975) Damned Whores and God's Police (Melbourne: Penguin Books).

Teale, R. (1978) Colonial Eve (Melbourne: Oxford University Press).

Vamplew, W. (1987) Australians: Historical Statistics (Sydney: Fairfax, Syme and Weldon Associates).

Ville, S. (1998) Business development in colonial Australia, Australian Economic History Review, 38(1), pp. $16-41$. 
Appendix A. Shareholders' general meetings of the bank of New South Wales - number of votes contributed by the proxy vote

\begin{tabular}{lcccccc}
\hline & \multicolumn{5}{c}{ Votes } \\
\cline { 2 - 7 } $\begin{array}{l}\text { Date of } \\
\text { meeting }\end{array}$ & $\begin{array}{c}\text { President } \\
\text { and } \\
\text { Directors }\end{array}$ & $\begin{array}{c}\text { Other } \\
\text { shareholders }\end{array}$ & $\begin{array}{c}\text { Available } \\
\text { female } \\
\text { proxies }\end{array}$ & $\begin{array}{c}\text { Female } \\
\text { proxies } \\
\text { used }\end{array}$ & $\begin{array}{c}\text { Total } \\
\text { votes } \\
\text { taken }\end{array}$ & $\begin{array}{c}\% \text { of proxy } \\
\text { votes used to } \\
\text { total votes }\end{array}$ \\
\hline $03-02-1818$ & 11 & 23 & 0 & 0 & 34 & 0.0 \\
$06-01-1819$ & 17 & 28 & 0 & 0 & 45 & 0.0 \\
$25-01-1819$ & 15 & 36 & 0 & 0 & 51 & 0.0 \\
$11-08-1819$ & 14 & 7 & 2 & 0 & 21 & 0.0 \\
$17-08-1819$ & 16 & 17 & 3 & 2 & 35 & 5.7 \\
$17-11-1819$ & 17 & 34 & 7 & 5 & 56 & 8.9 \\
$08-02-1820$ & 19 & 40 & 7 & 5 & 64 & 7.8 \\
$09-08-1820$ & 15 & 40 & 15 & 12 & 67 & 18.0 \\
$07-09-1820$ & 11 & 27 & 15 & 12 & 50 & 24.0 \\
\hline
\end{tabular}

Note: The number of votes to which each shareholder was entitled was not listed in subsequent general meetings so no further comparisons can be made. However, it is clear that the female proxy vote had a material effect. Source: WBC, BNSW Directors' Minute Book 1 (3 February 1818, 6 January 1819, 25 January 1819); Directors' Minute Book 2 (11 August 1819, 17 August 1819, 17 November 1819, 8 February 1820, 9 August 1820, 7 September 1820). 